\title{
Effects of Ski Resort Management on Vegetation
}

\author{
KUBOTA, Hitomi \\ SHIMANO, Koji \\ Faculty of Science, Shinshu University \\ 3-1-1 Asahi, Matsumoto City, 390-8621 Japan \\ shmano@shinshu-u.ac.jp
}

Tel \& fax: $+81-263-37-2445$

(for K.Shimano, the corresponding author)

\begin{abstract}
We investigated species composition and characteristics of plant communities in plots at seven site types within a ski resort: forests, an abandoned ski slope, an area under the gondola lines, forest waterfronts, open waterfronts, edges of ski slopes, and an active ski slope. On the abandoned ski slope, under the gondola lines, at the edges of ski slopes, and on the ski slope, canopy closure was low, tall herbs were present, and species diversity was high. Some wetland species were present at waterfront plots. Differential species composition was caused by vegetation cutting, which was necessary to manage the ski resort. We found various plants, including herbs, some of them are rarely seen because their habitats decreased. Despite their negative effects, such as soil surface
\end{abstract}


erosion and magnification of plant size due to the use of ammonium sulfate, ski resorts can be important plant habitats with highly diverse species composition. 


\section{Introduction}

The vegetation of ski areas includes varied habitats for plants, such as herbaceous ski slopes, wet sites, and surrounding coppice forests. Coppice forests traditionally provided wood for fuel, fertilizer from litter, and edible wild plants. However, in Japan, the use of wood for fuel was abandoned in the 1960s in favor of propane gas. Moreover, the use of fertilizer from coppice forests decreased as progress was made with chemical fertilizer (Tabata 1997). The floors of these abandoned forests have darkened. As a result, many coppice forests have experienced little growth of forest floor plants. Furthermore, forest management practices, such as thinning, are now rare, due to the decrease in timber-self sufficiency after late 1970s (Shimazaki 1999). Japanese timber is more expensive than foreign timber, the interest in silviculture as a career has decreased, and silviculturists are older (Nihon-Ringyo-Chosakai 2002). Hence, there are few herbaceous plants under the dense canopies of mature plantation forests due to the lack of thinning (Shimano et al. 2006).

Other herbaceous plant habitats have also decreased. The total area of rice fields in Japan is falling due to the decrease in rice acreage implemented by the Japanese government, smaller numbers of farmers, and the aging of current farmers (Department of Statistics Information, Ministry of Agriculture, Forestry and Fisheries of Japan 2000). The distribution area of aletophytes, including rice field forbs, is also decreasing with the 
use of agrichemicals (Tabata 1997; Hayashi and Tominaga 2004). A decrease of aletophytes is now feared (Serizawa 1995). Agricultural watercourses are being lined with concrete, and this habitat change is disturbing the distribution of many creatures (Kadono and Yuma 1995). Semi-natural meadows controlled by artificial burning are under succession to forests (Kurihara et al. 2001). Some plants, such as Hedyotis diffusa in rice fields and Swertia pseudochinensis in artificial meadows, are on the verge of extinction (Nagano Nature Conservation Research Institute 2002). Some semi-natural meadows serve as refugia for herbaceous plants (Suga 2008). But meadows dominated by Miscanthus sinensis are themselves endangered (Nagano Nature Conservation Research Institute 2005). The importance of semi-natural vegetation for endangered plant species continues to be emphasized (Fujii 1999, Nozaki 2007).

Ski resorts can have negative effects on plant communities, including the erosion of surface soil (Watson 1985), harmful effects for both plants and animals (Watanabe 1999; Bayfield 1980), and simplification of species composition and plant size magnification due to the use of ammonium sulfate to keep the snow cover from melting (Nakamura et al. 1999; Tatemoto and Nakamura 1999). However, ski resorts include many different plant habitats and may serve as refugia for herbaceous plants. Mowing and other ground cover management strategies may preserve plants that grow in secondary pastures.

Our study used vegetation surveys to clarify the role of ski resorts as refugia of herbaceous, wetland, and forest floor plants. At Fujimi Panorama Ski Resort in central 
Japan, we investigated how different sites and management strategies, such as mowing, provide habitat for various plants.

\section{Study Sites and Methods}

Study sites

Fujimi Panorama Ski Resort is located in Fujimi, Nagano Prefecture, central Japan (N 35 54', E 138 12'). It is open not only in winter but also in summer for mountain biking. Elevation ranges from 1,080 to $1,780 \mathrm{~m}$ above sea level on the east-facing slope of Mt. Nyukasa (altitude $1,955 \mathrm{~m}$ ). Annual mean temperature is $8.9^{\circ} \mathrm{C}$ in the lower elevations and $5.1^{\circ} \mathrm{C}$ in the higher elevations, and Kira's warmth index (WI; Kira 1949) is $67.7^{\circ} \mathrm{C} \cdot$ month. Kira's WI is the sum of mean monthly temperatures above $5^{\circ} \mathrm{C}: \mathrm{WI}=\Sigma$ (mean monthly temperature $-5^{\circ} \mathrm{C}$ ) only for warmer months averaging more than $5^{\circ} \mathrm{C}$. The unit is ${ }^{\circ} \mathrm{C} \cdot$ month. Annual precipitation is $1,412 \mathrm{~mm}$, snowfall is usually from December to March, and maximum snow depth is shallow, at about $0.27 \mathrm{~m}$ (Meteorological Bureau 2000). Climax vegetation is Pacific Ocean-type beech forest co-dominated by deciduous and evergreen coniferous trees, estimated from WI and maximum snow depth (Shimano 2006).

This resort area sustains varied vegetation types in sites such as forests, 
meadows on ski slopes, edges of ski slopes, and areas under gondola lines. We investigated species composition at these sites. The ski resort is surrounded by planted red pine (Pinus densiflora) and Japanese larch (Larix kaempferi) forests.

We established several plots at each of the following seven types of sites: (1) forests, (2) an abandoned ski slope, (3) an area under gondola lines, (4) forest waterfronts, (5) open waterfronts, (6) edges of ski slopes, and (7) an active ski slope. Each of these seven sites had a unique physiognomy, with homogeneous vegetation at each site type. In each site we set several plots for vegetation survey. Forests surrounded the ski slopes. $P$. densiflora and L. kaempferi dominated at heights of about $20 \mathrm{~m}$. Although natural $P$. densiflora forests sometimes occur in Japan on mountain ridges or rocky habitats, in Nagano prefecture many mountain slopes are covered with planted $P$. densiflora forests (Yokouchi 1979), such as those around the ski slopes. The abandoned ski slope had been in use until 3 years before. Herbs and trees were regenerating naturally. The plots under the gondola lines were deforested, with tall herbaceous plants that were cut every 3 or 4 years. This vegetation was different from that of both the forests and the active ski slope. Forest waterfronts were artificial unlined channels in which plants grew naturally. Open waterfronts were the sides of artificial unlined channels used for drainage. The bank soil had not been artificially compacted, and water flow was low. In these forest and open waterfronts, the water level fluctuates with precipitation, with high levels in the early summer rainy season, autumn typhoon season, and snow melt season. However, the water 
channels do not change. The vegetation along the edges of the ski slopes forms a belt between the ski slope and forests. Surveyed ski slope plots were in the center of the slopes and were mowed 3 or 4 times a year. Table 1 shows the frequency of cutting at each site according to resort officials.

Methods

Phytosociological investigation

We investigated species composition in each of 51 study plots at the 7 site types, using Braun-Blanquet's method (Braun-Blanquet 1964). The survey area, which differed in each plot, was set to encompass all of the species occurring in the plot. Plot sizes ranged from $2 \mathrm{~m}^{2}$ in open and forest waterfront (channel) plots to $400 \mathrm{~m}^{2}$ in forests. We identified the common species at each of the seven site types. Table 2 summarizes the species compositions of the sites. Scientific names are from Satake et al. (1989a, b). To calculate species diversity, we used the median of Braun-Blanquet's six-level cover degrees (+, 1 to 5) and calculated Shannon-Wiener's H' (bit).

We identified the Raunkiaer life form of all species (Raunkiaer 1934), using the divisions of Miyawaki et al. (1994) as follows: 
HH: Helophyte

Th: Therophyte

G: $\quad$ Geophyte

H: $\quad$ Hemicryptophyte

Ch: Chamaephyte

N: Nanophanerophyte

M: $\quad$ Mesophanerophyte

MM: Macrophanerophyte

We also recorded community heights. In coppice forests, community height minus planted trees was recorded to capture the natural growth of ground cover plants.

Measurement of canopy closure

To determine canopy closure as an index of light conditions, we took hemispherical photographs with a circular fisheye lens. We used a Coolpix 5400 digital camera with fisheye converter FC-E9 (Nikon, Tokyo, Japan). The camera was placed at a height of $1.5 \mathrm{~m}$ and set horizontally. After taking the pictures, we calculated the canopy closure rate with LIA 32 software for Windows (Yamamoto 2004). 


\section{Results}

Vegetation at each site type

In total, we found 297 species in the 51 plots. The vegetation of each of the seven main study sites had a typical species composition (see Table 2).

Forest plots

Forests consisted mainly of planted red pine (Pinus densiflora) and larch (Larix kaempferi). The forest floor was predominantly covered by shrubs (Ilex macropoda, Parabenzoin praecox, Viburnum dilatatum, and Rhus trichocarpa), vines (Rhus ambigua), various ferns, and dwarf bamboo (Sasa nipponica). On some forest floors, S. nipponica dominated instead of tree species such as red pine or larch. Herbs, such as Carex siderosticta and Disporum smilacinum, which are prevalent species on the forest floor or in dark and wet sites, were also distributed. Community heights, not including planted canopy trees, were $9.75 \pm 0.61 \mathrm{~m}$ (see Table 3 ), suggesting that the natural vegetation under canopy covers was mature.

Abandoned ski slope plots 
Plots at this site contained tall herbs (Miscanthus sinensis, Macleaya cordata, and Aster ageratoides ssp. ovatus) and young, shade-intolerant woody plants (Pinus densiflora, Betula platyphylla var. japonica, and Salix bakko). Species composition differed from that of the plots under the gondola lines, although both site types had altherbosa and shade-intolerant, woody plants. On the abandoned ski slope, the heights of B. platyphylla var. japonica and $P$. densiflora were about $1.5 \mathrm{~m}$, suggesting succession to woodlands.

Plots under the gondola lines

The site under the gondola lines was near forests and had the same brown forest soil; hence, the vegetation was similar to gap vegetation in the forests. The plots at this site were in between those of the ski slope and the forests. In the plots, altherbosa, such as Artemisia princeps, Vicia cracca, Patrinia villosa, Aster ageratoides ssp. ovatus, Senecio cannabifolius, Desmodium podocarpium ssp. oxyphyllum, and Eupatorium chinense var. oppositifolium, was dominant, along with woody plants, such as Parabenzoin praecox, Deutzia crenata, Alnus japonica, Aralia elata, Alnus hirsuta var. sibirica, Hydrangea hirta, Rhus javanica var. roxburgii, and Betula platyphylla var. japonica.. 
Sites at the edges of ski slopes

This site type, which was located between the ski slopes and forests, was distributed in a belt. Solidago virgaurea var. asiatica, Patrinia villosa, Eupatorium chinense var. oppositifolium, and Eupatorium chinense ssp. sachalinense were present as meadow herb species. We also found these species on the ski slope and along forest edges. In addition, we found Hedyotis diffusa, an endangered species in Nagano Prefecture.

Ski slope plots

Herbaceous plants such as Trifolium repens, Poa sphondylodes, and Festuca arundinacea grew on the ski slope. Trifolium repens and $F$. arundinacea are non-native species. We also found Hydrocotyle sibthorpioides, Kummerowia striata, Geranium thunbergii, and Artemisia princeps, which are lower-growing herbs.

Open waterfront sites

Open waterfronts contained the following herbaceous species: Scirpus wichurae (about $1 \mathrm{~m}$ tall) in the upper layers and Persicaria sieboldii, Carex dickinsii, Carex 
dispalata, Juncus effusus var. decipiens, Cyperus orthostachyus, Cyperus brevifolius var. leiolepis, and Hypericum laxum in the lower layers (less than $0.3 \mathrm{~m}$ tall). These plants, which grow on open waterfronts and paths between rice fields and wetlands, were not present at any of the other six sites.

Forest waterfront plots

We found the aletophytes Cryptotaenia japonica, Impatiens textori, Elatostema umbellatum var. majus, Hydrangea involucrata, Persicaria nepalensis, Chloranthus japonicus, and Boehmeria sylvestris growing in dark, wet sites in montane zones. These species were not found at any of the other six site types we surveyed.

Canopy closure

Canopy closures by fisheye photographs were low on the ski slopes but high in the forest site type (see Table 3). Closure values were lowest on the active and abandoned ski slopes. Values increased at the open waterfronts, ski slope edges, under the gondola lines, forest waterfronts, and forests (see Table 3). There were significant differences between each relationship among sites, although there was no significant difference between forests and forest waterfronts, between the abandoned ski slope and the site 
under the gondola lines, between the active and abandoned ski slope, and between the ski slope and open waterfronts (analysis of variance; protected least significant difference: PLSD).

Canopy closure and herb layer cover

Figure 1 shows the relationship between canopy closure and herb layer cover. We excluded dwarf bamboo, Sasa nipponica, in determining the relationship between forest floor brightness and herbaceous plant coverage, as dwarf bamboo reproduces by rhizome, and this cover does not reflect forest floor brightness. No canopy trees occurred on either the edges of the ski slopes or under the gondola lines, so canopy closure rates were low, but not zero because of the effects of surrounding forests. We found a significant negative correlation between canopy closure and ground cover $(p<0.01)$; thus, ground coverage decreased when canopy closure rate increased.

Raunkiaer's life forms

Higher vegetation tended to include more woody plants (see Fig. 2). In particular, the forest site type had many $\mathrm{M}$ and $\mathrm{MM}$ species, and $80 \%$ of the flora was woody species. The proportion of MM, M, and N species increased, and that of Th, G, and H species (e.g., 
herbs) decreased from the ski slope to the forest ( $p<0.001$, Spearman's rank method). H predominated in almost all site types but made up only $8 \%$ of vegetation in forests. In both forest and open waterfront sites, aletophytes of $\mathrm{HH}$ were common. The proportion of $\mathrm{N}$ at the abandoned ski slope, forest waterfronts, and site under the gondola lines was higher than that on the active ski slope.

Species diversity

Table 3 shows average species diversity according to Shannon-Wiener's H' (bit). The highest diversity index value was for forest waterfronts $(M=4.51 \mathrm{bit})$, followed by the site under the gondola lines, edges of the ski slope, open waterfronts, the abandoned ski slope, the active ski slope, and forests $(M=2.93 \mathrm{bit})$. Analysis of variance revealed that although there was no significant difference among forest, ski slope, and abandoned ski slope sites, such sites were significantly different from forest waterfronts, which had high species diversity $(p<0.01)$. Moreover, the ski slope and forest sites were significantly different from the edges of the ski slope and the site under the gondola lines $(p<0.01)$

Canopy closure was highest in forest plots $(80.1 \pm 3.7 \%$; see Table 3$)$, and the diversity index was low. In contrast, canopy closure was lowest on the ski slope, but diversity was also low there, suggesting no direct relationship between canopy closure 
and species diversity (see Table 3).

\section{Discussion}

Species characteristics of each site type

Forests

On the forest floor, we found typical plants of coppice forests, including Rhus trichocarpa, Ilex macropoda, Rhus ambigua, Viburnum dilatatum, and Parabenzoin praecox, which are common in Pinus densiflora forests. Rhus trichocarpa and $V$. dilatatum are typical of Larix plantations (Suzuki 1985), and I. macropoda grows in coppice forests (Miyawaki 1985). Parabenzoin praecox is characteristic of the Parabenzoin praecocis-Zelcovetum association and grows on concave slopes of mountain valleys and colluvial deposits (Miyawaki 1985). These species are common in P. densiflora and L. kaempferi plantations.

Abandoned ski slope

The abandoned ski slope was home to many shade-intolerant plants, such as 
Miscanthus sinensis, Pinus densiflora, Solidago virgaurea var. asiatica, Lysimachia clethroides, Aster ageratoides ssp. ovatus, Patrinia villosa, Viola grypoceras, Haloragis micrantha, Anaphalis margaritacea, and Swertia pseudochinensis (see Table 2). Pinus densiflora was representative of shade-intolerant trees. Solidago virgaurea var. asiatica, Lysimachia clethroides, Aster ageratoides ssp. ovatus, and Viola grypoceras are characteristic of Arundinello-Miscanthion sinensis, a late succession community that follows Geranio-Zoysietum japonicae associations after grazing and burning are terminated (Kim 1985). Patrinia villosa, Haloragis micrantha, and Anaphalis margaritacea are primary components of the Miscanthus sinensis community. Swertia pseudochinensis is characteristic of the Swertia japonica subassociation of Arundinario chino-Miscanthetum sinensis, which typifies secondary meadow. These species and their community were taller than those of the ski slope, suggesting a succession from the ski slope.

Species diversity at the abandoned ski slope was less than that of the site under the gondola lines (see Table 3), although the time of the last mowing was the same. This suggests that forces other than mowing may affect species diversity. Betula platyphylla var. japonica and Pinus densiflora were dominant, and the trees were not germinated from stump or soil-seed pools but from newly dispersed anemochorous seeds. Koyama and Koyama (2002) also pointed out that surrounding vegetation affects the recovery of trees on abandoned ski slopes. 
$\mathrm{N}, \mathrm{M}$, and MM species were more common here than on the active ski slope, as the invasion of woody plants coincided with the termination of mowing.

Site under the gondola lines

Plots at the site under the gondola lines contained shade-intolerant trees, shrubs, and perennial herbs as follows: Aralia elata, Rubus crataegifolius, Rubus palmatus var. coptophyllus, Patrinia villosa, Pteridium aquilinum var. latiusculum, Lysimachia clethroides, Senecio cannabifolius, Aster ageratoides ssp. ovatus, Petasites japonicus, Macleaya cordata, Artemisia princeps, Senecio cannabifolius, Anaphalis margaritacea, Eupatorium chinense var. oppositifolium, and Cynoglossum asperrimum. Aralia elata, Rubus crataegifolius, and Rubus palmatus var. coptophyllus are shade-intolerant woody plants growing in logged areas, and Petasites japonicus is a pioneer perennial herb growing in bare soil (Murakami 1985). In logged areas, we saw different vegetation that depended on human disturbance. The perennial herbs Artemisia princeps, Lysimachia clethroides, and Pteridium aquilinum var. latiusculum were found in the Aralia elata-Rubus palmatus var. coptophyllus community; the shade-intolerant scrubs Aralia elata, Rubus crataegifolius, Rubus palmatus var. coptophyllus, and Macleaya cordata are characteristic of Youngio denticulatae-Macleayetum cordatae; and Senecio cannabifolius and Anaphalis margaritacea occur in Eupatorio-Epilobietum angustifolii and 
Anaphalido-Aruncetum kamtsuchatici, respectively (Murakami 1985). These

associations are herb communities in an intermediate phase of succession. It is striking that some so-called tall herbs, such as Eupatorium chinense var. oppositifolium, Senecio cannabifolius, and Cynoglossum asperrimum, had heights ranging from 1.5 to $2 \mathrm{~m}$.

This type of community depends on low, frequent mowing every 3 or 4 years, which results in high species diversity (see Table 3 ). More than $40 \%$ of woody species were high in the herbaceous community, and N, M, and MM species were highly dominant (see Fig. 2). In contrast, annual and perennial species occurred in Th, G, H, and Ch. Each Th, G, H, and Ch life form represented more than $8 \%$ of the flora at these plots. The fact that both woody and herbaceous plants grew under the gondola lines highlights the high species diversity of this site type.

Edges of ski slopes

The site on the edges of the ski slopes supported secondary meadow and logged-forest species like Patrinia villosa, Solidago virgaurea var. asiatica, Eupatorium chinense var. oppositifolium, Cirsium oligophyllum, Reynoutria japonica, Petasites japonicus, Eupatorium chinense ssp. sachalinense, Rubia argyi, Clematis apiifolia, Viola grypoceras, Geranium thunbergii, and Trifolium repens. All of these, as well as the average community height, were taller than the herbs on the ski slope (Table 3). Patrinia 
villosa, Solidago virgaurea var. asiatica, Eupatorium chinense var. oppositifolium, Cirsium oligophyllum, Petasites japonicus, and Viola grypoceras are characteristic of Miscanthion sinensis in Miscanthetea sinensis associations of secondary meadows (Kim 1985). Patrinia villosa, Eupatorium chinense var. oppositifolium, Petasites japonicus, Eupatorium chinense ssp. sachalinense, and Reynoutria japonica are common in logged forest vegetation and landslide scar vegetation of Petasiti japonici-Aralietalia cordatae associations (Murakami 1985). Reynoutria japonica, Eupatorium chinense ssp. sachalinense, Viola grypoceras, Rubia argyi, and Geranium thunbergii are found in half-shaded forest-edge herb communities (Murakami 1985). Of ski slope species, Poa sphondylodes and Trifolium repens were also found here. Thus, the vegetation consisted of secondary grasslands of Miscanthus sinensis, logged-forest vegetation, landslide scar vegetation, forest edge vegetation, and ski slope vegetation.

Species diversity was high at the edges of ski slopes (see Table 3). Patrinia villosa, Solidago virgaurea var. asiatica, and Cirsium oligophyllum are species of secondary meadows of Utsukushigahara and Kirigamine highlands (Murakami 1985, Miyawaki 1994).

Compared to those of the ski slope, rates of $\mathrm{Ch}, \mathrm{N}, \mathrm{M}$, and $\mathrm{MM}$ were higher at the edges of the ski slopes. This implies that much taller species can grow in the edge site, which is less mowed than the ski slope (Table 1). 
Ski slope

On the ski slope, we found Poa sphondylodes, Trifolium repens, Stenactis annuиs, Kummerowia striata, Geranium thunbergii, Festuca arundinacea, Artemisia princeps, Erigeron canadensis, Solidago virgaurea var. asiatica, Hydrocotyle sibthorpioides and Plantago asiatica (see Table 2).Trifolium repens and Festuca arundinacea originated from seeds sown during the creation of the ski slope. Such pasture grasses have also been reported on a ski slope in Hakuba, Nagano Prefecture (Nakamura 1988). Geranium thunbergii, Artemisia princeps, Kummerowia striata, Erigeron canadensis, and Solidago virgaurea var. asiatica are common species of Geranio-Zoysietum japonicae associations of Zoysion japonicae in Miscanthetea sinensis; the species composition of Geranio-Zoysietum japonicae associations is like grazing ground (Miyawaki et al. 1994). The Zoysia japonica community is low-height pasture due to human disturbances, such as grazing, burning, mowing, and trampling (Kim 1985). In addition, in some plots we found Hydrocotyle sibthorpioides and Plantago asiatica, which are resistant to trampling. Such low plants are common because of mowing on the ski slope and trampling by sightseers and mountain bikes (see Table 1). Moreover, the Zoysia japonica community retrogressively successes to Plantaginetalia asiaticae with more simple species composition due to excessive mowing or trampling (Kim 1985). In lower parts of the ski slope, we found high cover of Plantago asiatica, 
suggesting that such retrogressive succession might be occurring. In a ski slope in Tobu-Yunomaru, Nagano Prefecture, Nakamura (1988) reported that Plantago asiatica, Trifolium repens, and Dactylis glomerata grew as a result of heavy trampling.

Canopy closure here was the lowest (Table 3), and plants grew in sunny conditions. H dominated the flora. The ski slope rates of N, M, and MM were the lowest among the study sites. This reflects the frequency of mowing, which was the highest among the study sites (Table 1). Species diversity here is also low due to heavy mowing.

Open waterfronts

Open waterfronts supported wetland species such as Scirpus wichurae, Hypericum laxum, Persicaria sieboldii, Carex dispalata, Juncus leschenaultii, Cyperus brevifolius var. leiolepis, and Cyperus orthostachyus (see Table 2). Scirpus wichurae and Hypericum laxum are members of the Isachno-Caricetum thunbergii association of low moor vegetation. Low moor vegetation occurs in areas of standing water due to incoming water and poor discharge in valley bottoms in mountain areas or back marshes of rivers (Okuda 1985). Okuda pointed out that this community also occurs in fallow rice fields as an intermediate phase of succession. Carex dispalata is characteristic of Caricetum dispalatae, one of the most widespread forms of low moor vegetation. Caricetum dispalatae usually occurs in large-scale back marshes and sometimes occurs in a belt 
along the edges of flowing water in mountainous areas (Okuda 1985). Juncus

leschenaultii, Hypericum laxum, Cyperus brevifolius, and Persicaria sieboldii have been found in Juncus leschenaultii communities in wet paddy fields abandoned for 1 year (Shimoda 1996). Cyperus brevifolius var. leiolepis is a typical plant of Eupatorium lindleyanum-Ischaemum aristatum var. glaucum communities in year-round wet rice fields abandoned for 2 or 3 years. Cyperus orthostachyus is also characteristic of Vandellietum angustifoliae associations of riparian flood herbaceous vegetation that occur in riparian sites that experience overhead flooding during the rainy season (Okuda 1985) and where succession is delayed by water flow disturbances. This Vandellietum angustifoliae site, in sedimentary mud along the waterfront, was typical of riparian vegetation sometimes affected by floods.

The open waterfront plots contained species typically found in low moor vegetation, abandoned rice fields, and riparian flood herbaceous vegetation. The unlined channel we surveyed was artificial and unpaved. Canopy openness was high, and the site was brightly lit (see Fig. 1 and Table 3), with slow and low water flow (pers. obs.). This is a similar environment to rice fields and natural wetlands. Wetland vegetation has decreased throughout Japan because of the decrease in natural wetlands and rice fields (Kadono and Yuma 1995, Geographical Survey Institute, Japan 2000, Sasaki 2001, Ohkuro et al. 2003). Therefore, open waterfronts at ski resorts will play a role as hydrophyte and aletophyte habitat in the face of declining wetlands and rice fields. 
Forest waterfronts

Forest waterfronts were home to Impatiens textori, Cryptotaenia japonica, Elatostema umbellatum var. majus, Hydrangea involucrata, Persicaria nepalensis, Boehmeria sylvestris, and Chloranthus japonicus. Ohno (1985) noted that E. umbellatum var. majus and Hydrangea involucrata are widespread forest floor species in various mountain riparian communities. Persicaria nepalensis is found in high-moisture sites, such as wetlands or on paths between rice fields, I. textori in shaded wetlands and flowing waterfronts, and C. japonica on forest floors. B. sylvestris, C. japonicus, and E. umbellatum var. majus are common in Zelkova serrata riparian forests in Pacific Ocean climates.

These species occur in wet environments, such as riparian areas, waterfronts, and valleys, and we found these plants among shaded, wet vegetation. This site type had species in common with natural riparian forests, although the artificial channel was beside a forest road. Thus, the species composition here was similar to that of natural waterfront habitats in mountainous areas.

The forest waterfront site type had the highest $\mathrm{H}^{\prime}$ values for species diversity $(4.51 \pm 0.39$ bit; see Table 3$)$ due to water flow disturbance. The environment was characterized by high moisture and shade beneath the forest canopy. 
Change in life forms

The forest site had many N, M, and MM trees (Fig. 2) due to the lack of mowing. In contrast, the other six site types had many Th, G, H, and Ch herb species. At waterfront plots, water flow disturbance delayed succession. The ski slope, abandoned ski slope, and site under the gondola lines were affected by mowing. These different disturbance regimes resulted in differences in life form composition between the forest and other site types. Although N plants were common at the abandoned ski slope, forest waterfronts, and the site under the gondola lines, their values were less than those for the forest. This suggests that disturbances like mowing or water flow at the former three sites were less than that at the ski slope.

Role of ski resorts

Two factors affect vegetation in the ski resort studied. The first is habitat condition, including water and light. In the ski-resort waterfronts, many species are those of natural waterfronts. The distribution of species in open- and closed-canopy waterfronts differs by canopy openness. Closed-canopy waterfronts contain mountain riparian species (Ohno 1985) such as Elatostema umbellatum var. majus, Hydrangea involucrate, and Impatiens textori, whereas open-canopy waterfronts contain low moor species 
(Okuda 1985) such as Scirpus wichurae, Hypericum laxum, and Carex dispalata.

The second factor is the frequency of mowing related to resort management. Different site types experience different frequencies of mowing (Table 1) and different rates of vegetation succession following the disturbance (Fig. 2). It is difficult for ski slope vegetation to mature because of frequent mowing (3 times per year). The abandoned ski slope and the site under the gondola lines, where the frequency of mowing is not high (Table 1), have tall vegetation and varied herb species. In contrast, forest plot communities are typical of artificial Pinus densiflora and Larix kaempferi forests.

The vegetation found in the ski resort is a complex combination of rice field, waterfront, secondary meadow, forest landslide scar, and logged area species. Each site type has a specific plant community (Table 2). For example, the open waterfront community plays the same role as do rice fields and natural waterfronts. Some species typical of low moors or rice fields, such as Scirpus wichura, Hypericum laxum, Juncus leschenaultii, and Persicaria sieboldii, are present (Table 2; Okuda1985, Shimoda and Suzuki 1981). Waterfronts under forests contain Elatostema umbellatum var. majus and Hydrangea involucrate, which are mountain riparian forest species (Ohno 1985). The sites at the edges of ski slopes and under the gondola lines contain vegetation found in forest landslide scars and secondary meadows. For example, Macleaya cordata, Patrinia villosa, Eupatorium chinense, and Petasites japonicus occur in forest landslide scar and logged areas (Murakami 1985, Kim 1985). The abandoned ski slope site is like a 
secondary meadow, with Solidago virgaurea, Aster ageratoides spp.ovatus, and Patrinia villosa (Miyawaki et al. 1994).

The resort is a refugium for various species, some of which are endangered, such as as Hedyotis diffusa, found in sites at the edges of ski slopes, and Swertia pseudochinensis, found in the abandoned ski slope site. Moreover, although many waterfront species are not necessarily endangered, waterfront habitats are decreasing (Kadono and Yuma 1995, Sasaki 2001, Ohkuro et al. 2003, Geographical Survey Institute, Japan 2000). Altherbosa in rice fields is also decreasing due to agricultural chemical use, the decrease in rice fields, and the increase of cemented banks (Tabata 1997). At the ski resort, waterfront habitats are not likely to change, and the resort studied does not use agricultural chemicals at its waterfront sites. Therefore, these communities are more natural than their counterparts in rice fields. Semi-natural meadows are also considered to be refugia for herbaceous plants (Suga 2008). These Miscanthus-sinensis-dominated meadows are also endangered (Nagano Nature Conservation Research Institute 2005). Not only is meadowland disappearing in Japan (Kurihara et al. 2001), but so are herbaceous species of well-managed secondary and artificial forests because of shade conditions. Coppice and artificial forests used for timber are being abandoned, as these resources are no longer needed for fertilizer and fuel, and timber from developing countries is inexpensive (Tabata 1997; Nihon-Ringho-Chosakai 2002). However, the ski resort preserves semi-natural meadow habitats at the edges of ski slopes and on 
abandoned ski slopes, where Patrinia villosa, Haloragis micrantha,Eupatorium chinense var. oppositifolium, and other meadow species are present (Table 2). The total area of such waterfronts and secondary meadows may not be large, but these sites are important, because management will help maintain species distribution in the long term. In this respect, ski resorts play a role in the conservation and diversity of herb species. Furthermore, ski resorts also play a role in the ecological education of young people. Resorts are usually easy to access and have facilities such as restrooms, gondolas, and/or lifts. Thus, people who are not comfortable hiking or climbing mountains can easily use ski resorts to learn about ecology and nature.

\section{Acknowledgments}

Mr. K. Takeuchi and Mr. T. Hatanaka of Shinshu University assisted greatly with our field survey. Fujimi Panorama Resort Company and its members also provided support. Dr. Akira Hiruma, a curator of Iida City Museum, offered helpful suggestions on constructing a synthetic table. We appreciate their help very much.

\section{Literature cited}

Braun-Blanquet J (1964) Pflanzensoziologie: Grundzüge der Vegetationskunde. 3rd edn. Springer-Verlag, Wien, 3. Aufl. 865pp 
Bayfield NG (1980) Replacement of vegetation on disturbed ground near ski lifts in the Cairngorm Mountains, Scotland. J Biogeogra 7:249-260

Department of statistics information, the Ministry of Agriculture, Forestry and Fisheries of Japan (2000) World senses of agriculture and forestry in 2000. Norin-Tokei-kyoukai, Tokyo. (in Japanese)

Fujii S (1999) A comparative analysis of habitat types of locally endangered plants in Japan. Jpn j conserv ecol 4:57-69. (in Japanese with English abstract)

Geographical Survey Institute, Japan (2000)

http://www1.gsi.go.jp/geowww/lake/shicchimenseki2.html

Hayashi H Tominaga T (2004) Effects of mowing on levee flora. The scientific reports of Kyoto Prefectural University. Human environment and agriculture 59:109-113 (in Japanese)

Kadono Y Yuma M (1995) Nature of wetland. 198pp Hoikusya, Osaka. (in Japanese)

Kim S (1985) Sekundärwiesen. In: Miyawaki A (ed.) Vegetation of Japan: Chubu. Shibundo Publisher Co., LTD., Tokyo: pp 176-192 (in Japanese)

Kira $\mathrm{T}$ (1949) Forest zone in Japan. Forestry explanation series 17, Nippon-Ringyo-Gijutsu- Kyokai,Tokyo (in Japanese).

Koyama Y, Koyama K (2002) Vegetation change for 20-year period at abandoned ski slopes in northern Nagano Prefecture. Bulletin of the Institute of Nature Education in Shiga Heights, Shinshu University 39:1-6 (in Japanese and English summary)

Kurihara M, Iuchi M, Furuya K (2001) A study on the succession and the preservation technique on 
secondary grassland in Kirigamine. Environmental information science. Extra, Papers on environmental information science 15:215-220 (in Japanese and English abstract)

Miyawaki A (ed.) (1985) Vegetation of Japan: Chubu. Shibundo Publisher Co., LTD., Tokyo (in Japanese)

Miyawaki A, Okuda S, Fujiwara R (1994) Handbook of Japanese Vegetation (new revised edition). Shibundo, Tokyo. 910pp (in Japanese)

Meteorological bureau, Japan (2000) Meshed meteorological data. Meteorological bureau, Japan.

Murakami Y (1985) Wegrand- und Wald-Saumgesellschaften. In: Miyawaki A (ed.) Vegetation of Japan: Chubu. Shibundo Publisher Co., LTD., Tokyo: pp 213-219 (in Japanese)

Nakamura T, (1988) Phytosociological study on the vegetation at Skiing grounds in Japan. Memoirs of Institute of Agriculture and Forestry, the University of Tsukuba. Agricultural and forestry science 4:1-142. (in Japanese with English summary)

Nakamura T (1999b) A review of scientific studies on ski areas in Japan. Jpn J Ecol 49: 261-264 (in Japanese)

Nakamura T, Tatemoto Y, Kamijo T (1999) Effects of ammonium sulfate on vegetation on ski runs subjected to differing degrees of landscaping. Veg Sci 16:141-147 (in Japanese with English abstract)

Nagano Nature Conservation Research Institute (2002) Red data book of plants in Nagano Prefecture. Environment and Nature conservation section, Life environment department, Nagano Prefecture. 297pp. Nagano City, Japan. (in Japanese) 
Nagano Nature Conservation Research Institute (2005) Red data book of plants in Nagano Prefecture

-Non tracheophyta species and plant communities-. Environment and Nature conservation section, Life environment department, Nagano Prefecture. 205pp Nagano City, Japan. (in Japanese)

Nihon-Ringyo-Chosakai (2002) Data book of forests and timbers 2002 111pp. Nihon-Ringyo-Chosakai, Tokyo. (in Japanese)

Nozaki R (2007) Natural history of summer-green oak (Quercus) forest with special reference to the nature conservation of seminatural vegetation of Japan. Bulletin of Kansai Organization for Nature Conservation 29: 127-142

Okuda S (1985) Auenwiesen-Gesellschaften. In: Miyawaki A (ed.) Vegetation of Japan: Chubu. Shibundo Publisher Co., LTD., Tokyo: pp 159-171 (in Japanese)

Ohkuro T, Shirato Y, Itoh, K (2003) Environmental characteristics of abandoned paddy fields contribution to the persistence of the population of a threatened plant species Penthorum chinense. J Jpn Inst Landscape Archi 66: 599-602.

Ohno K (1985) Bachrinnenwälder in der mountanen Stufe. In: Miyawaki, A. (ed.) Vegetation of Japan: Chubu. Shibundo Publisher Co., LTD., Tokyo: pp 256-262 (in Japanese)

Raunkiaer C (1934) The life forms of plants and statistical plant geography. The Clarendon Press, Oxford.

Sasaki M. (2001) Distribution of breeding colonies of herons and egrets and their protection in Kyoto Prefecture. Strix 19: 149-160 (In Japanese with English abstract)

Satake Y, Hara H, Watari S, Tominari T (1989) Wild flowers of Japan. Woody plants I . Heibonsha 
Ltd., Publishers, Tokyo: pp321 (In Japanese)

Satake Y, Hara H, Watari S, Tominari T (1989) Wild flowers of Japan. Woody plants II. Heibonsha Ltd., Publishers, Tokyo: pp305 (In Japanese)

Serizawa S (1995) Nature in country town. Hoikusha, Osaka: pp196 (In Japanese)

Shimano K (2006) Differences in beech (Fagus crenata) regeneration between two types of Japanese beech forest and along snow gradient. Ecol Res. 21:651-663.

Shimano K, Yatake H, Nashimoto M, Shiraki S, Matsuki R (2006) Habitat availability and density estimations for the Japanese hare by fecal pellet counting. J Wildlife Manage 70:1651-1658.

Shimazaki Y (1999) I will undertake silvicultural management. Kawabe-Shorin, Nagano. (in Japanese. The title was temporally translated by the authors)

Shimoda M (1996) Abandoned rice field vegetation and its evaluation: A case study of wet abandoned rice field vegetation in Hiroshima prefecture. Veg Sci 13:37-50. (in Japanese and English abstract)

Shimoda M, Suzuki H (1981) Vegetation of fallow rice fields in the Saijo Basin, Hiroshima Prefecture, Japan. Hikobia Supplement 1:321-339. (in Japanese with English summary)

Suga T (2008) Historical change of semi-natural grasslands in the central mountainous area of Japan and their implications for conservation of grassland species. Bulletion of Nagano environmental conservation research institute 4:17-31 (in Japanese with English abstract)

Suzuki S (1985) Nadelholz-reiche Sekundärwälder. In: Miyawaki A (ed.) Vegetation of Japan: Chubu. Shibundo Publisher Co., LTD., Tokyo: pp 176-192 (in Japanese)

Tabata H (1997) Nature of country areas. Hoikusha, Osaka. 199pp. (in Japanese) 
Tatemoto Y, Nakamura T (1998) The actual situation of using ammonium sulfate in skiing areas. Jpn Outdoor Edu J 2:13-19 (in Japanese and English summary)

Watanabe R (1999) Development of ski resort and nature conservation in Nagano. Jpn J Ecol 49:277-281 (in Japanese)

Watson A (1985) Soil erosion and vegetation damage near ski lifts at Cairn Gorm. Scotland Biol Conserv. 33:363-381

Yamamoto K (2004) http://www.agr.nagoya-u.ac.jp/ shinkan/LIA32/index-e.html

Yokouchi F (1979) Pinus densiflora forst. Vegetation of Nagano Prefecture. In: Arbeitsgemeinschaft für die Vegetationskartierung der Präfektur Nagano. Reale Vegetation der Präfektur Nagano: Eine pflanzensoziologishe Studie für den Natur und Umweltschutz, sowie die Schaffung eines vegetationsreichen Landes der Präfektur Nagano, Präfektur Nagano, pp 287-288 (in Japanese with German summary) 


\section{Captions}

Figure 1. Relationship between canopy closure of trees and coverage of herb layer.

Figure 2. Ratios of Raunkiaer's life form in seven site types.

HH: Helophyte, Th: Therophyte, G: Geophyte, H: Hemicryptophyte, Ch: Chamaephyte,

N: Nanophanerophyte, M: Mesophanerophyte, MM: Macrophanerophyte. 


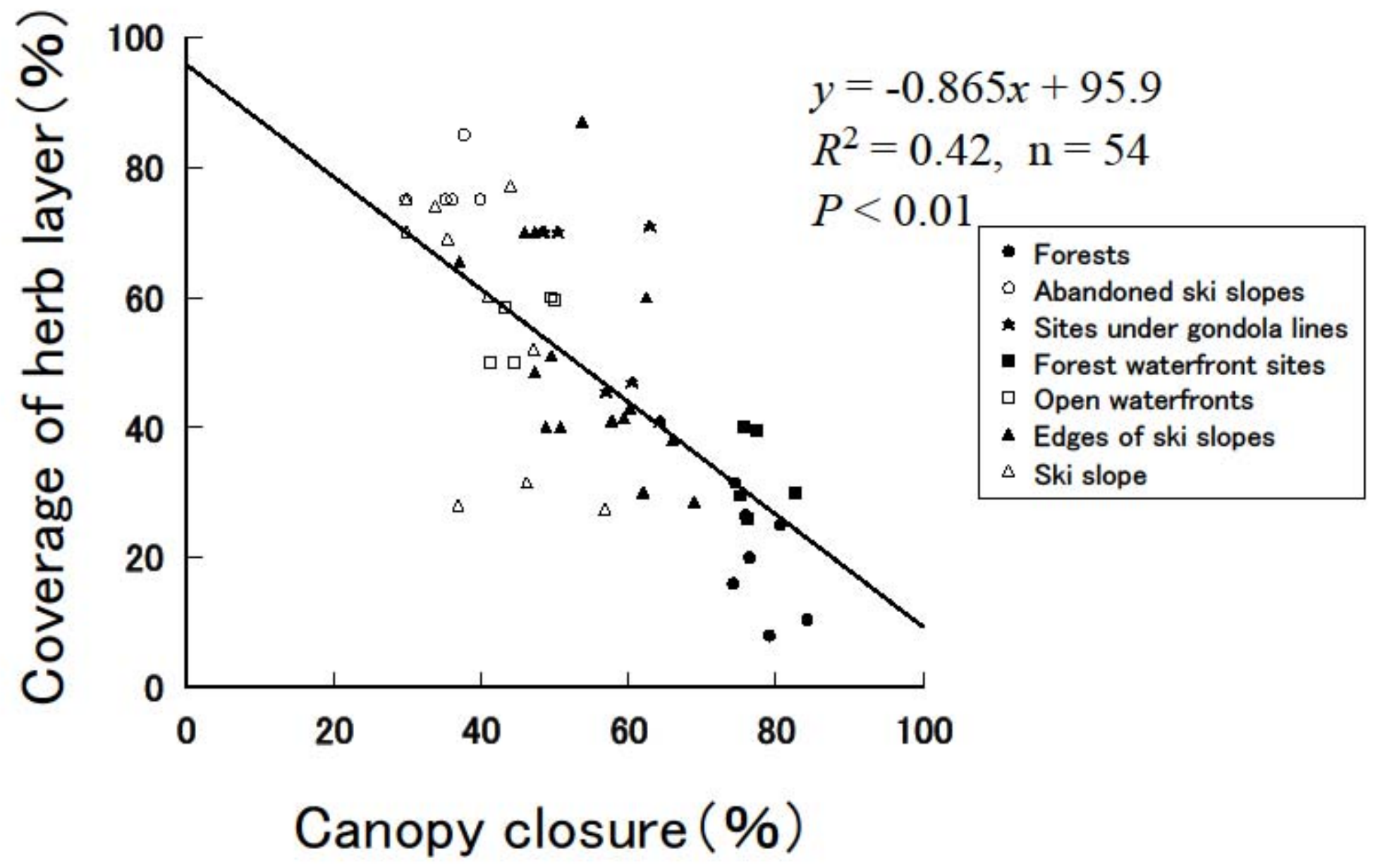

Figure 1. 


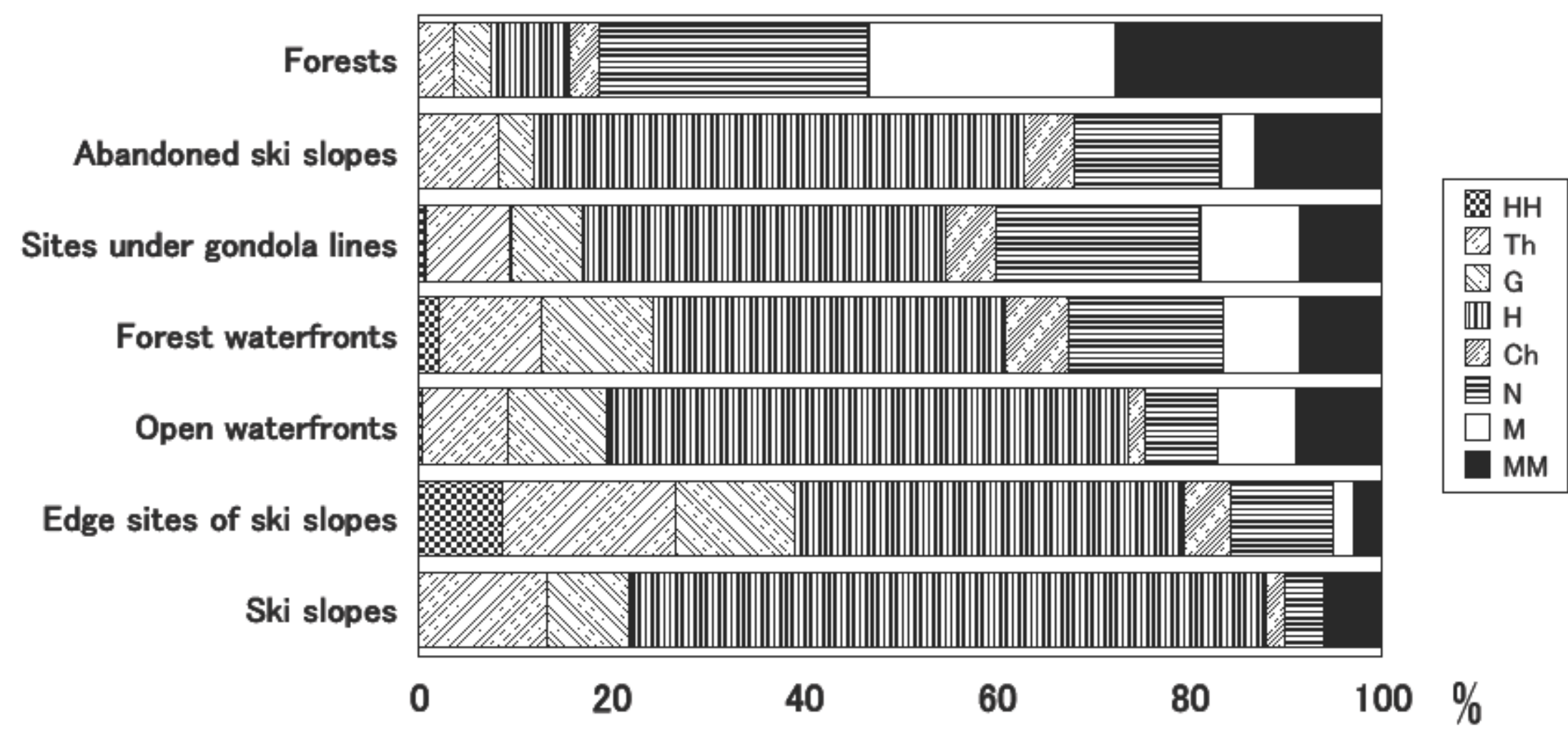

Figure 2. 
Table 1. Characters and managements of each site.

\begin{tabular}{lllcc}
\hline & Sites & Situation & aximum community heights & Mowing management \\
\hline 1 & Forests & stands of Pinus densiflora and Larix kaempferi & $20 \mathrm{~m}$ & No \\
2 & Abandoned ski slopes & Pasture of weed and shade intolerant woods & $1.5 \mathrm{~m}$ & Abundant in three years \\
3 & Sites under gondola lines & Secondary pasture & $1.3 \mathrm{~m}$ & mowed every 3 or 4 years \\
4 & Forest waterfronts & unlined ditch for drainage under forest canopy & $0.8 \mathrm{~m}$ & No \\
5 & Open waterfronts & Altherbosa along unlined ditch for drainage in open ai & $0.8 \mathrm{~m}$ & No \\
6 & Edges of skislopes & Secondary pasture between forests and ski slopes & $1.3 \mathrm{~m}$ & No \\
7 & Ski slopes & Weeds & $0.8 \mathrm{~m}$ & 6 \\
\hline
\end{tabular}


Table 2. Synthetic table of seven sites in Fujimi ski resort.

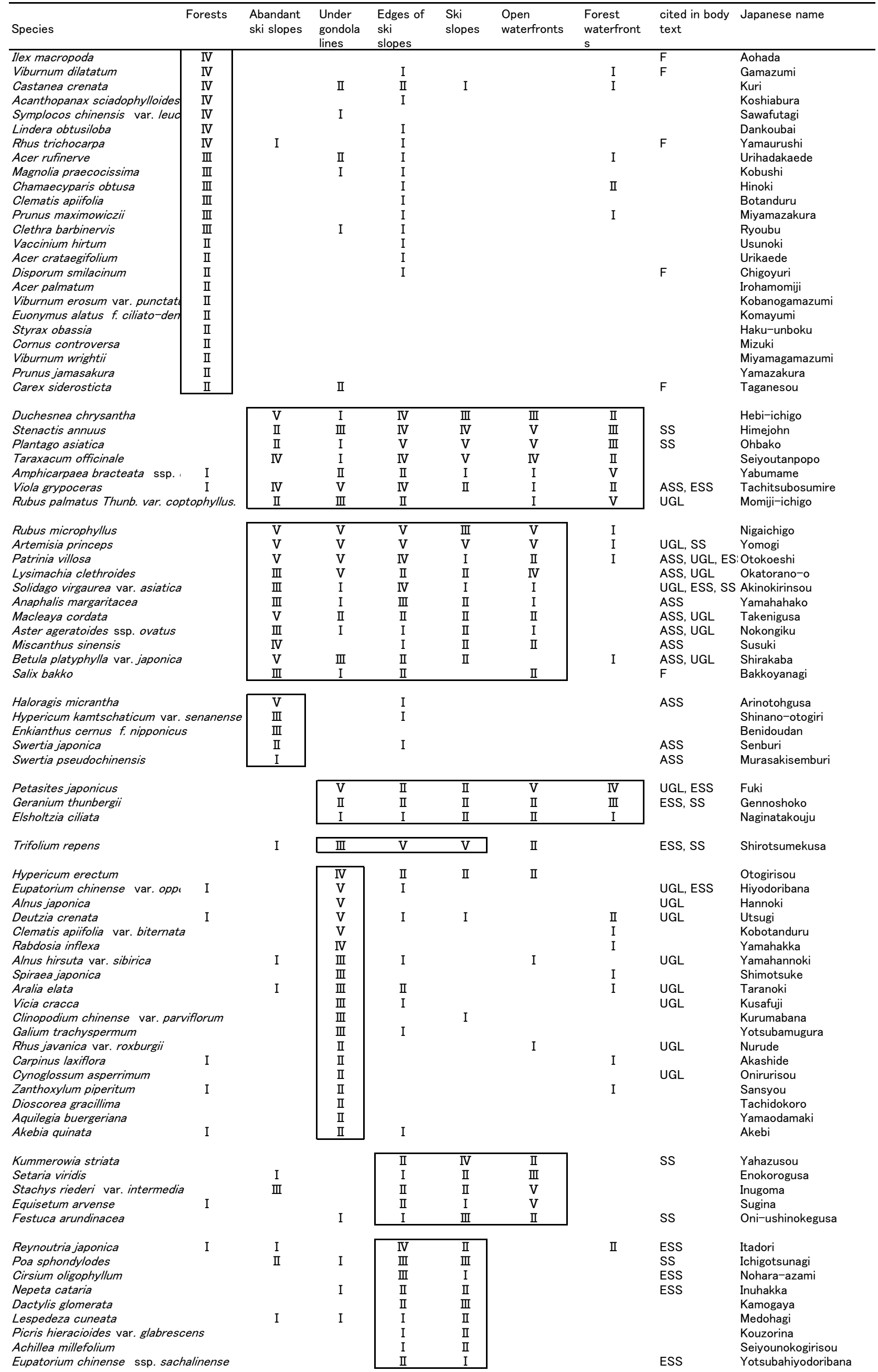




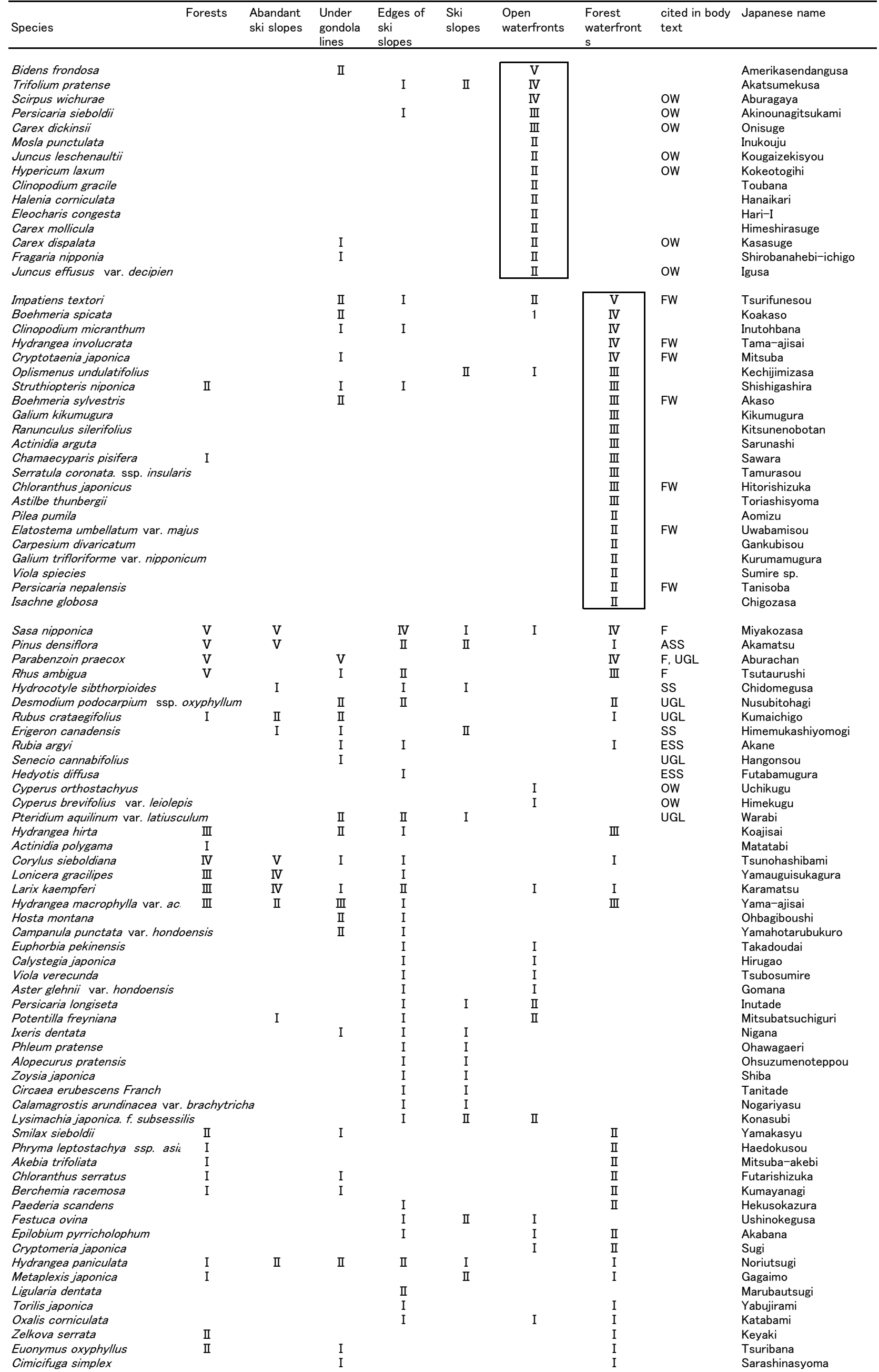




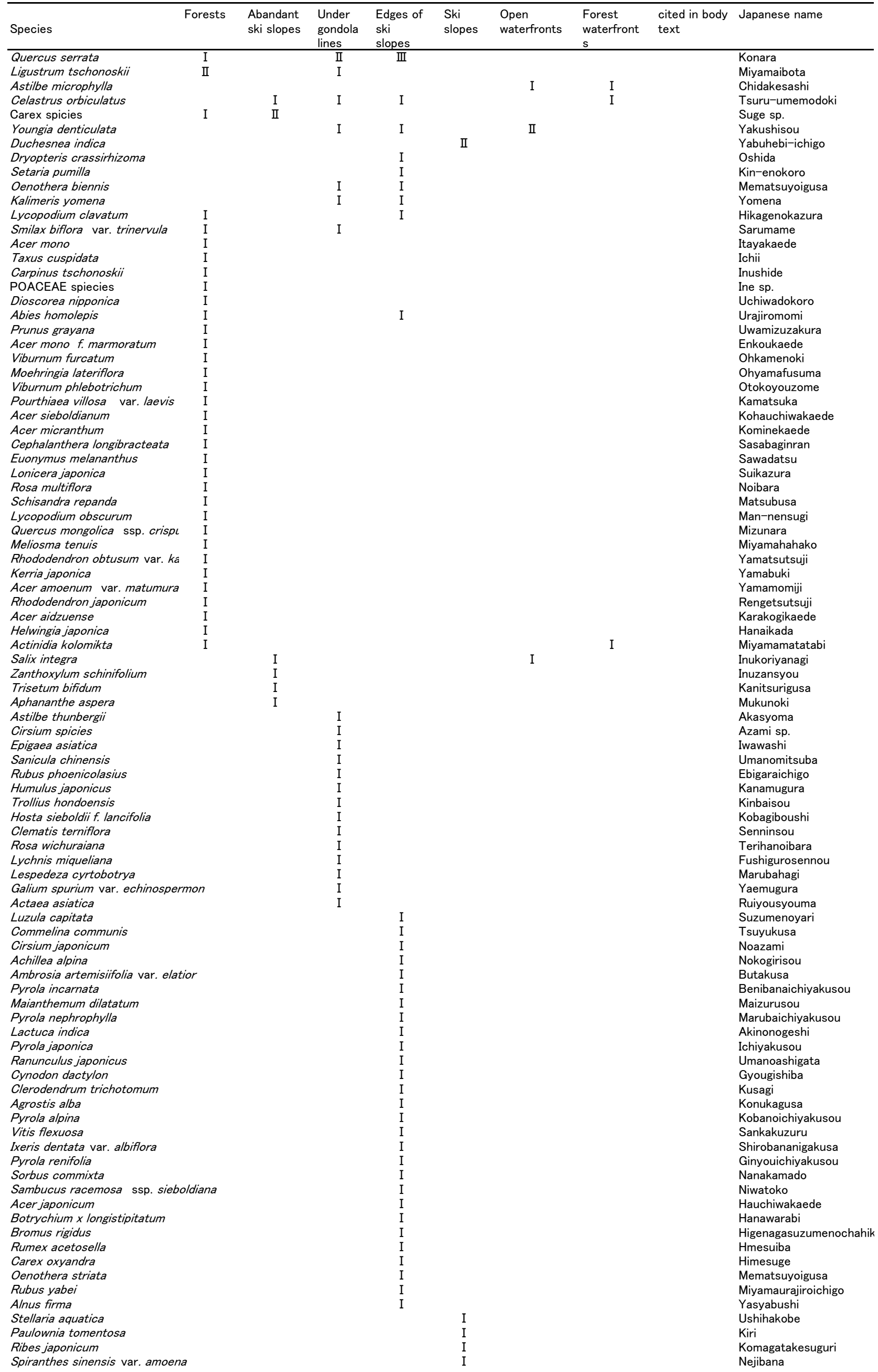




\begin{tabular}{|c|c|c|c|c|c|c|c|c|}
\hline Forests & $\begin{array}{l}\text { Abandant } \\
\text { ski slopes }\end{array}$ & $\begin{array}{l}\text { Under } \\
\text { gondola } \\
\text { lines }\end{array}$ & $\begin{array}{l}\text { Edges of } \\
\text { ski } \\
\text { slopes }\end{array}$ & $\begin{array}{l}\text { Ski } \\
\text { slopes }\end{array}$ & $\begin{array}{l}\text { Open } \\
\text { waterfronts }\end{array}$ & $\begin{array}{l}\text { Forest } \\
\text { waterfront } \\
\text { s }\end{array}$ & $\begin{array}{l}\text { cited in body } \\
\text { text }\end{array}$ & Japanese name \\
\hline \multicolumn{4}{|l|}{ Lolium perenne } & I & & & & Hosomugi \\
\hline \multicolumn{4}{|l|}{ Veronica japonensis } & I & & & & Yamakugawata \\
\hline \multicolumn{4}{|l|}{ Persicaria pubescens } & I & & & & Bontokutade \\
\hline \multicolumn{4}{|l|}{ Bistorta major var. japonica } & & I & & & Ibukitoranoh \\
\hline \multicolumn{4}{|l|}{ Prunella vulgaris. ssp. asiatica } & & I & & & Utsubogusa \\
\hline \multicolumn{4}{|l|}{ Agrimonia japonica } & & $\mathrm{I}$ & & & Kinmizuhiki \\
\hline \multicolumn{4}{|l|}{ Aletris foliata } & & I & & & Nebarinogiran \\
\hline \multicolumn{4}{|l|}{ Lotus corniculatus var. japonicus } & & I & & & Miyakogusa \\
\hline \multicolumn{4}{|l|}{ Fimbristylis subbispicata } & & I & & & Yamai \\
\hline \multicolumn{4}{|l|}{ Fraxinus lanuginosa f. serrata } & & & I & & Aodamo \\
\hline \multicolumn{4}{|l|}{ Swertia bimaculata } & & & $\mathrm{I}$ & & Akebonosou \\
\hline \multicolumn{4}{|l|}{ Microstegium vimineum var. polystachyum } & & & I & & Ashiboso \\
\hline \multicolumn{4}{|l|}{ Schizophragma hydrangeoides } & & & $\mathrm{I}$ & & Iwagarami \\
\hline \multicolumn{4}{|l|}{ Diospyros kaki } & & & I & & Kakinoki \\
\hline \multicolumn{4}{|c|}{ Rabdosia shikokiana var. lecantha $f$. kameba } & & & $\mathrm{I}$ & & Kamebahikiokoshi \\
\hline \multicolumn{4}{|c|}{ Boehmeria gracilis } & & & I & & Kusakoakaso \\
\hline \multicolumn{4}{|l|}{ Bistorta suffulta } & & & $\mathrm{I}$ & & Kurinyukifude \\
\hline \multicolumn{4}{|l|}{ Senecio nikoensis } & & & I & & Sawagiku \\
\hline \multicolumn{4}{|l|}{ Weigela decora } & & & $\mathrm{I}$ & & Nishikiutsugi \\
\hline \multicolumn{4}{|l|}{ Arabis hirsuta } & & & I & & Yamahatazao \\
\hline \multicolumn{4}{|l|}{ Clematis japonica } & & & I & & Hansyoduru \\
\hline \multicolumn{4}{|l|}{ Arisaema serratum } & & & $\mathrm{I}$ & & Mamushigusa \\
\hline \multicolumn{4}{|l|}{ Euonymus sieboldianus } & & & $\mathrm{I}$ & & Mayumi \\
\hline \multicolumn{4}{|l|}{ Chrysosplenium ramosum } & & & I & & Marubanekonome \\
\hline \multicolumn{4}{|l|}{ Clinopodium sachalinense } & & & I & & Miyamatoubana \\
\hline \multicolumn{4}{|l|}{ Laportea bulbifera } & & & I & & Mukagoirakusa \\
\hline \multicolumn{4}{|l|}{ Tricyrtis affinis } & & & I & & Yamajinohototogisu \\
\hline \multicolumn{4}{|l|}{ Aconitum japonicum } & & & $\mathrm{I}$ & & Yamatorikabuto \\
\hline \multicolumn{4}{|l|}{ Malus toringo } & & & I & & Zumi \\
\hline
\end{tabular}

Roman numbers show frequency as follows: $0<\mathrm{I}<20 \%, 20 \leq \mathrm{II}<40 \%, 40 \leq \mathrm{III}<60 \%, 60 \leq \mathrm{IV}<80 \%, 80 \% \leq \mathrm{V}$

Abbreviations: F: forest, ASS: abandant ski slopes, UGL: under gondola lines, ESS: edges of ski slopes, OW: open waterfronts, FW: forest waterfronts 
Table 3. Mean and S.D. of canopy heights, canopy closures and diversities in each site type.

\begin{tabular}{|c|c|c|c|c|c|c|c|}
\hline & & \multicolumn{2}{|c|}{ Mean community heights $(\mathrm{m})$} & \multicolumn{2}{|c|}{ Canopy closure (\%) } & \multicolumn{2}{|c|}{ Species diversity (H' bit) } \\
\hline 1 & Forests & $9.75 \pm 0.61$ & $a$ & $77.9 \pm 3.7$ & $a$ & $2.93 \pm 0.83$ & $a$ \\
\hline 2 & Abandoned ski slopes & $1.36 \pm 0.31$ & $b$ & $35.8 \pm 3.7$ & $b, d$ & $3.33 \pm 0.53$ & $b$ \\
\hline 3 & Sites under gondola line & $0.97 \pm 0.38$ & c & $56.0 \pm 6.9$ & c & $4.16 \pm 0.54$ & c \\
\hline 4 & Forest waterfronts & $0.77 \pm 0.08$ & c & $77.5 \pm 3.0$ & a & $4.51 \pm 0.39$ & $d$ \\
\hline 5 & Open waterfronts & $0.74 \pm 0.26$ & $c, d$ & $45.8 \pm 3.9$ & c & $3.79 \pm 0.48$ & b, c \\
\hline 6 & Edges of skislopes & $0.74 \pm 0.13$ & c & $54.5 \pm 8.8$ & d & $3.96 \pm 0.37$ & c \\
\hline 7 & Ski slopes & $0.41 \pm 0.30$ & $d$ & $41.3 \pm 8.2$ & $d$ & $3.26 \pm 0.74$ & a \\
\hline
\end{tabular}

Different alphabets shows the significant differences among them (ANOVA, Fisher's PLSD. $p<0.05$ ). 